Gut, 1975, 16, 177-180

\title{
Serum pyridoxal in active peptic ulceration
}

\author{
C. R. SANDERSON ${ }^{1}$ AND R. E. DAVIS \\ From the Royal Perth Hospital, Perth, Western Austraia
}

SUMMARY Fasting serum pyridoxal was assayed by an automated microbiological system in 50 patients with endoscopically confirmed active peptic ulceration. Thirty patients had gastric ulceration, 14 had duodenal, four had pyloric canal ulceration, and two had both a gastric and a duodenal ulcer. Serum pyridoxal was below normal in 28 of the gastric ulcer group and in one of the duodenal ulcer troup. No difference in the age, sex, drug, alcohol intake, or diet could be distinguished between those two groups.

The terms vitamin $B_{6}$ and pyridoxine are often used synonymously; however, vitamin $\mathbf{B}_{6}$ is a general term used to include three closely related, naturally occurring compounds whose metabolism is closely interlinked: pyridoxine, pyridoxamine, and pyridoxal. Man is able to utilize all three, but it is generally accepted that only the phosphorylated form of pyridoxal has biological activity (Gunsalus, Bellamy, and Umbreit, 1944) and it has been estimated that pyridoxal-5-phosphate acts as a coenzyme in at least 50 enzymatic reactions (Sauberlich, 1968).

Investigations of vitamin $B_{6}$ in health and disease have, in the past, relied upon the measurement of both absolute and relative amounts of urinary breakdown products (Lepkovsky, Roboz, and Haagen-Smit, 1943; Lerner, De Carli, and Davidson, 1958; Price, Brown, and Yess, 1965; Brown, Thornton, and Price, 1961; Brown, Rose, Price, and Wolf, 1969; Horrigan and Harris, 1964; MacGibbon and Mollin, 1965). Bioassay techniques have been used, but are indirect, have a considerable margin of error, are expensive and tedious to perform and consequently are not suited to the study of large groups. Serum pyridoxal-5-phosphate has been estimated via enzymatic methods (Chabner and Livingston, 1970) and microbiological assay systems (Anderson, Peart, and Fulford-Jones, 1970), and it would seem logical that measurement of the active principle would give more relevant information regarding the state of vitamin $\mathbf{B}_{6}$ metabolism.

With the development in our hospital of an auto-

\footnotetext{
${ }^{1}$ Address for future correspondence: Dr C. R. Sanderson, Gastroenterology Unit, Royal Perth Hospital, Wellington Street, Perth, W.A. 6000

Received for publication 4 December 1974.
}

mated microbiological system for the assay of serum pyridoxal (Davis, Smith, and Curnow, 1973) we have been able to investigate large groups with a wide range of conditions. As part of a series of in vestigations, some already reported (Davis and Smith, $1974 a$ and $b$ ), this paper records the results of our study of serum pyridoxal levels in patients with active peptic ulceration.

\section{Materials and Methods}

Blood was taken from fasting patients before upper gastrointestinal endoscopy. The serum was separated and stored at $-20^{\circ} \mathrm{C}$ until required for assay. Patients who in the month preceding endoscopy had had either an overt gastrointestinal bleed or received a blood transfusion were excluded from this study.

Pyridoxal was assayed by an automated microbiological technique using Lactobacillus casei as the test organism (Davis et al, 1973) and the reference range is related to age and sex (vide infra).

Serum folate was assayed by the method of Davis, Nicol, and Kelly (1970) using $L$. casei as the test organism (reference range 2.5-18.3 $\mu \mathrm{g} / \mathrm{l}$ ) and vitamin $B_{12}$ by the method of Nicholas and Pitney (Nicholas and Pitney, 1958) using Euglena gracilis as the test organism (reference range $\mathbf{1 6 0 - 8 7 5} \mathrm{ng} / \mathrm{l}$ ).

In over $95 \%$ of cases the instrument used for endoscopy was the Olympus GIF type D. In seven patients blood was taken before premedication, usually pethidine and atropine, and again immediately preceding endoscopy. At no time before the estimation of the vitamin levels was the laboratory aware of the clinical or endoscopic diagnosis, nor informed of any drugs that the patients had taken within one week of endoscopy. 


\section{Results}

Fifty patients (30 outpatients and 20 inpatients) were investigated. Ages ranged from 24 to 78 with a mean of 53 years. There were 24 males and 26 females.

Three patients had serum $B_{12}$ levels above normal $(970,1000$, and $1050 \mathrm{ng} / \mathrm{l})$ and none had levels below normal.

Serum folate was below normal in 11 patients and serum pyridoxal was below normal in 32 patients. Correlation between the two vitamin levels in individual patients is shown in figure 1.

Serum pyridoxal levels normally decrease with age and are slightly lower in females. Correlations between pyridoxal levels and age are shown in figure 2 (males) and figure 3 (females). It will be seen

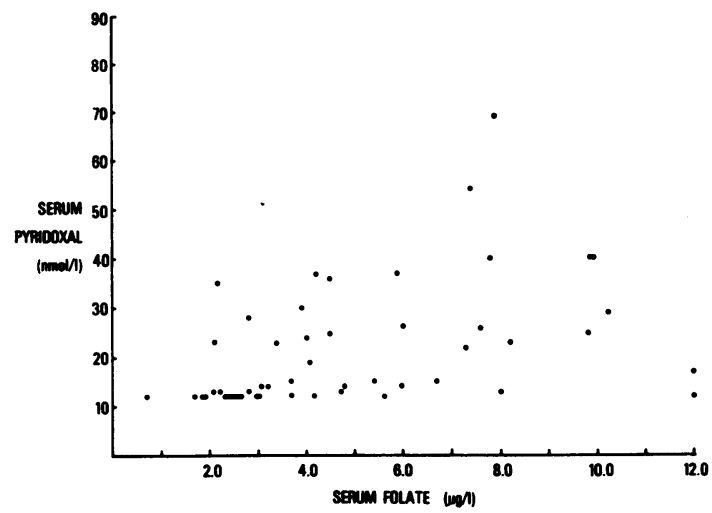

Fig 1 Serum pyridoxal/serum folate in individual patients with active peptic ulceration

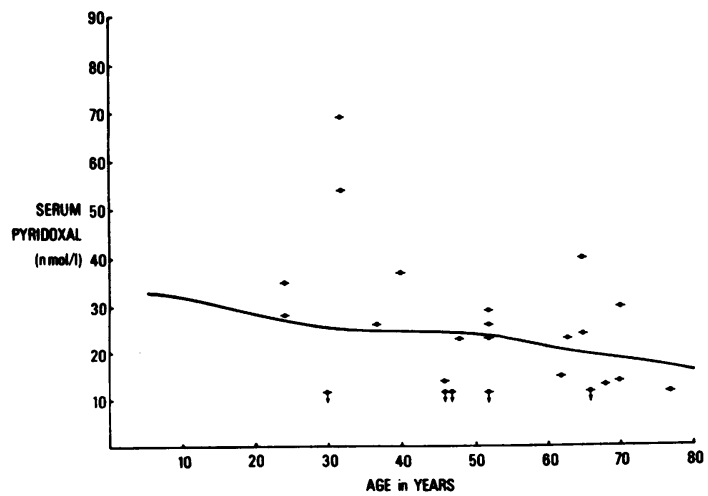

Fig 2 Serum pyridoxal/age in males with active peptic ulceration

( values less than $12 \mathrm{nmol} / \mathrm{l}$ )

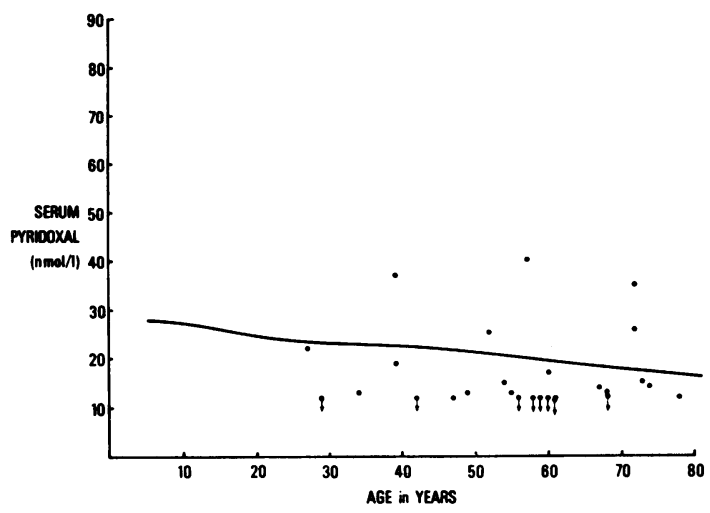

Fig 3 Serum pyridoxallage in females with active peptic ulceration

( $:$ values less than $12 \mathrm{nmol} / \mathrm{l}$ )

that in 11 males and 21 females the serum pyridoxal was below normal.

Comparison between pyridoxal levels before and after premedication are shown in table I. No significant difference is seen in the seven patients investigated, six of whom had low levels.

\begin{tabular}{llllllll}
\hline & \multicolumn{2}{l}{ Patient No. } & & & & \\
\cline { 2 - 8 } & 1 & 2 & 3 & 4 & 5 & 6 & 7 \\
\hline Before & $<12$ & 14 & 14 & 18 & 21 & 22 & 39 \\
After & $<12$ & 12 & 15 & 18 & 20 & 24 & 42 \\
\hline
\end{tabular}

Table I Variation in serum pyridoxal with premedication

When the site of ulceration was correlated with serum pyridoxal a striking difference emerged. Of 16 patients (13 males and three females) with active duodenal ulceration, 13 had normal serum pyridoxal levels and in two of the three with low levels coincident gastric ulceration was present. Pyloric canal ulceration was found in four patients and one had a low serum pyridoxal. Thirty patients, eight males and 22 females, had active gastric ulceration and 28 had a low serum pyridoxal level.

\begin{tabular}{lllll}
\hline & Gastric & Duodenal & $\begin{array}{l}\text { Pyloric } \\
\text { Canal }\end{array}$ & $\begin{array}{l}\text { Gastric and } \\
\text { Duodenal }\end{array}$ \\
\hline Males & $7 / 8$ & $1 / 11$ & $1 / 3$ & $2 / 2$ \\
Females & $21 / 22$ & $0 / 3$ & $0 / 1$ & 0 \\
Total & $28 / 30$ & $1 / 14$ & $1 / 4$ & $2 / 2$ \\
\hline
\end{tabular}

Table II Correlation between sex, site of ulceration, and low serum puridoxal 


\begin{tabular}{lccrrlll}
\hline & No. & $\begin{array}{l}\text { Mean } \\
\text { Age } \\
(y r)\end{array}$ & \multicolumn{1}{l}{ Sex } & \multicolumn{2}{l}{$\begin{array}{l}\text { Mean Serum } \\
\text { Folate } \\
(\mu g / h)\end{array}$} & $\begin{array}{l}\text { Mean Serum } \\
\text { Pyridoxal } \\
(\text { nmol/l) }\end{array}$ \\
\hline Gastric & 30 & $54 \cdot 1$ & 8 & 22 & 4.6 & 14.7 \\
Duodenal & 14 & 51.3 & 11 & 3 & 5.3 & 30.8 \\
\hline
\end{tabular}

Table III Correlation between age, sex, serum folate, and serum pyridoxal in patients with active gastric or duodenal ulceration

${ }^{1}$ Because we are unable accurately to assay levels below $12 \mathrm{nmol} / \mathrm{l}$, values below this figure are assumed to be $11 \mathrm{nmol} / 1$ for the purpose of this comparison.

Correlation between sex, site of ulceration, and low serum pyridoxal levels are shown in table II, and excluding those patients with pyloric canal ulceration and coincident gastric and duodenal ulcers, analysis between the gastric and duodenal ulcer groups is shown in table III.

\section{Discussion}

Low serum pyridoxal levels in the gastric ulcer group compared with normal levels in the duodenal ulcer group could be the result of different diet, alcohol intake, drug therapy, or age between the two groups.

A diet deficient in vitamin $B_{6}$ would probably also be deficient in folate, and although the gastric ulcer group had a lower mean level of folate compared with the duodenal ulcer group, no correlation between individual levels was found. In patients with a gastric ulcer the serum folate levels varied between 0.7 and $20.0 \mu \mathrm{g} / \mathrm{l}$ and in the duodenal ulcer group between 2.1 and $9.8 \mu \mathrm{g} / 1$, and although serum pyridoxal levels tended to be low when serum folate levels were below $2.5 \mu \mathrm{g} / 1$, the folate varied between 0.7 and $20.0 \mu \mathrm{g} / 1$ when the serum pyridoxal level was below $12 \mathrm{nmol} / \mathrm{l}$. Vilter (1956) has suggested that a hospital diet might contain less than the recommended $2.5 \mathrm{mg} /$ day of vitamin $\mathbf{B}_{6}$ (National Research Council, 1968), but as the majority of our patients (30 out of 50:17 with gastric ulcers, nine with duodenal ulcers) were outpatients, it is unlikely that this factor is responsible for the difference between the two groups. Although we did not elicit detailed dietary histories, we could not detect any marked difference between the two groups of patients regarding their diet, and furthermore it seems unlikely that the patients could have segregated themselves before the actual site of the ulceration was determined.

Surveys (Davis and Smith, 1974; Lumeng and Li, 1974) of alcoholic patients have shown that about half have low serum pyridoxal levels, but in our group only two patients admitted to a regular large intake of alcohol immediately preceding investigation. One, with a duodenal ulcer, had a normal pyridoxal level and a low folate level and the other with a gastric ulcer had a low pyridoxal level and a normal folate level. One patient, with a gastric ulcer, was known to have had a regular large intake of alcohol up to three months before investigation, and in this patient both vitamin levels were low.

No patient was receiving anticonvulsant therapy, L-dopa, isoniazid or penicillamine, therapy previously reported (Biehl and Vilter, 1954; Evered, 1971; Hagberg, Hamfelt, and Hansson, 1966; Hollister, Moore, Forrest, and Bennett, 1966) to be associated with abnormalities of vitamin $\mathbf{B}_{6}$ metabolism. One was receiving an oral contraceptive agent and none were taking vitamin preparations. The combination of pethidine and atropine given as premedication did not significantly alter the serum pyridoxal levels in the seven patients investigated.

Serum pyridoxal levels decrease with advancing age but there is only a minor difference between the mean age of both groups in our study. Furthermore, two patients with duodenal ulcers and normal pyridoxal levels were over 70 years.

Although there is a distinct sex difference between the duodenal ulcer and the gastric ulcer group, the levels of serum pyridoxal in patients of the minority sex in both groups fit within the overall group pattern.

Because we cannot quantitate levels below 12 $\mathrm{mmol} / \mathrm{l}$, it is impossible to compare accurately the various sites of ulceration within the stomach; however, there did not appear to be any obvious increase in the levels of serum pyridoxal as the site of ulceration became more distal.

Considering the ubiquity of pyridoxal-5-phosphate as a coenzyme it is not surprising that abnormalities of serum pyridoxal levels should occur in active peptic ulceration, but the difference between the low levels with active gastric ulceration and the normal levels with active duodenal ulceration is puzzling. Drugs, including alcohol, age, and sex do not appear to be relevant and we do not believe that dietary factors are of prime importance. The difference may reflect differing biochemical bases between the two groups, or it may be the result of the ulceration itself, and follow-up studies which we are presently undertaking may help to resolve this particular question.

We should like to acknowledge the assistance received from Dr T. E. Waters and Dr R. L. Leedman, physicians of the Royal Perth Hospital, Mr Ralph Green of the Vitamin Assay Laboratory of Royal Perth Hospital, and Miss Christine Coleman in the preparation of this paper. 


\section{References}

Anderson, B. B., Peart, M. B., and Fulford-Jones, C. E. (1970). The measurement of serum pyridoxal by a microbiological assay using Lactobacillus casei. J. clin. Path., 23, 232-242.

Biehl, J. P., and Vilter, R. W. (1954). Effect of isoniazid in vitamin B, metabolism: its possible significance in producing isoniazid neuritis. Proc. Soc. exp. Biol. (N.Y.), 85, 389-392.

Brown, R. R., Rose, D. P., Price, J. M., and Wolf, H. (1969). Tryptophan metabolism as affected by anovulatory agents. Ann. N.Y. Acad. Sci., 166, 44-56.

Brown, R. R., Thornton, M. J., and Price, J. M. (1961). The effect of vitamin supplementation on the urinary excretion of tryptophan metabolites by pregnant women. J. clin. Invest., 40, 617-623.

Chabner, B., and Livingston, D. (1970). A simple enzymic assay for pyridoxal phosphate. Ann. Biochem., 34, 413-423.

Davis, R. E., Nicol, D. J., and Kelly, A. (1970). An automated method for the measurement of folate activity. J. clin. Path., 23, 47-53.

Davis, R. E., and Smith, B. K. (1974a). Pyridoxal and folate deficiency in alcoholics. Med. J. Aust., 2, 357-360.

Davis, R. E., and Smith, B. K. (1974b). Pyridoxal, vitamin $B_{18}$ and folate metabolism in women taking oral contraceptive agents. S. Afr. med.J., 48, 1937-1940.

Davis, R. E., Smith, B. K., and Curnow, D. H. (1973). An automated method for the microbiological assay of serum pyridoxal. $J$. clin. Path., 26, 871-874.

Evered, D. F. (1971). L-dopa as a vitamin $B_{6}$ antagonist. (Letter.) Lancet, 1,914.

Gunsalus, I. C., Bellamy, W. D., and Umbreit, W. W. (1944). A phosphorylated derivative of pyridoxal as the coenzyme of tyrosine decarboxylase. J. biol. Chem., 155, 685-686.
Hagberg, B., Hamfelt, A., and Hansson, O. (1966). Tryptophan level tests and pyridoxal-5-phosphate levels in epileptic children. Acta paediat. scand., 55, 371-384.

Hollister, L. E., Moore, F. F., Forrest, F., and Bennett, J. L. (1966). Antipyridoxine effect of D-penicillamine in schizophrenic men. Amer.J. clin. Nutr., 19, 307-312.

Horrigan, D. L., and Harris, J. W. (1964). Pyridoxine-responsive anemia : analysis of 62 cases. Advanc. intern. Med., 12, 103-174.

Lepkovsky, S., Roboz, E., Haagen-Smit, A. J. (1943). Xanthurenic acid and its role in the tryptophane metabolism of pyridoxinedeficient rats. J. biol. Chem., 149, 195-201.

Lerner, A. M., De Carli, L. M., and Davidson, C. S. (1958). Association of pyridoxine deficiency and convulsions in alcoholics. Proc. Soc. exp. Biol. (N.Y.), 98, 841-843.

Lumeng, L., and $\mathrm{Li}, \mathrm{T}$. K. (1974). Vitamin $\mathrm{B}_{\mathrm{o}}$ metabolism in chronic alcohol abuse. J. clin. Invest., 53, 693-704.

MacGibbon, B. H., and Mollin, D. L. (1965). Sideroblastic anaemia in man: observations on seventy cases. Brit. J. Haemat., 11 59-69.

National Research Council (1968). Recommended Dietary Allowances: A Report of the Food and Nutrition Board. National Academy of Sciences, Washington, D.C.

Nicholas, D. R., and Pitney, W. R. (1958). Microbiological assay of vitamin $\mathrm{B}_{12}$ content of serum using Euglena gracilis. Aust. J. exp. Biol.med. Sci., 36, 603-608.

Price, J. M., Brown, R. R., and Yess, N. (1965). Testing the functional capacity of the tryptophan-niacin pathway in man by analysis of urinary metabolites. Advanc. metab. Dis., 2, 159-225.

Sauberlich, H. E. (1968). In The Vitamins, edited by W. H. Sebrell and R. S. Harris, vol. 2, pp. 44-80. Academic Press, New York.

Vilter, R. W. (1956). The metabolism of vitamin $B_{8}$ in human beings. Amer.J. clin. Nutr., 4, 378-385. 